\title{
Conceptualizing Labour Union
}

\section{Revitalization}

\author{
Martin Behrens \\ Wirstschafts-und-Sozialwissenschaftliches Institute
}

Kerstin Hamann

University of Central Florida

Richard Hurd

Cornell University

\begin{abstract}
INTRODUCTION
Unions have engaged in revitalization efforts in all five country cases that form the basis of comparison of this book, though they differ in the strategies they have pursued and the level of success they have had. Some of the strategies have been promising or even successful in terms of their immediate outcomes; others are still waiting to be fully implemented; and still others have failed to live up to the original expectations. While in many countries union activists are eagerly developing strategies to turn their fate, they are also facing some doubt or even resistance by politicians and academics alike who question the need for a strong and unified representation of labour. Here, we set out to provide a conceptual framework to understand better these various efforts at revival of national union movements.

The following section discusses existing analyses of union revitalization and argues that a comparative perspective is well suited to shed light on unions' revitalization efforts. We then introduce different analytical perspectives on the role of labour in the economy, politics, and society to help identify the significance of unions in an ever more global economy. The next section outlines the parameters of crisis for unions by tracing indicators of union strength over time. We then suggest a framework for conceptualizing union revitalization as a multidimensional process and argue that revitalization has different meanings depending on the specific national context.
\end{abstract}

\section{UNION REVITALIZATION: THE NEED FOR COMPARATIVE ANALYSIS}

An emerging literature, assessing the strategies that union movements have adopted to stem their decline in membership and influence, can be categorized along two principal dimensions: first, whether the focus lies on a single country or multiple countries; and second whether it analyses one particular strategy or a range of strategies.

Examples of single strategy, one country studies include Bronfenbrenner et al. (1998) on organizing in the United States, Gall (2003) on organizing in Britain, Clawson (2003) on coalition-building in the United States and the edited collections 
on international action by US unions from Gordon and Turner (2000) and Nissen (2002). The dominant research method in these collections is the qualitative case study of a single campaign, typically involving a Thick description' of processes, events, and outcomes. Their results indicate, for example, that union success in boosting membership is more likely if an internal organizing committee exists and if the workforce shares a widespread sense of grievance (Bronfenbrenner and Juravich 1998; Taylor and Bain 2003). The volume of resources devoted to union organizing appears to depend heavily on union leadership commitment, and in some cases leadership change was a prerequisite to shifting union policy towards increased organizing (Voss and Sherman 2003).

However, the single-strategy, one country-approach is limited by three weaknesses. First, the case study method means that it is difficult to establish the contribution of a particular strategy, such as organizing, to aggregate union membership change. It is clear that under appropriate conditions union organizing can secure new members and new bargaining relations with employers. What is not clear is whether it can therefore revitalize a national union movement and notably boost total union membership. Second, the absence of comparative data on other strategies means that it is difficult to identify the relative costs and benefits of organizing as compared to social partnership or various forms of political action, for instance. Nor is it clear whether and how these strategies interact. For example, does organizing work better if used in conjunction with social partnership? Finally, the focus on a single country means that it is difficult to generalize to other countries and to identify the broader economic and political conditions that affect the success of specific strategies.

A second body of literature has also focused on a single country but examined a wide range of union strategies, both conventional and innovative (or 'field enlarging' to use Wever's 1997 term). Turner, Katz, and Hurd's (2001) collection on the United States is perhaps the best example (see also Kelly and Willman 2004 on the United Kingdom and Wheeler 2002 on the United States). It contains analyses of organizing, local and national political action, innovations in collective bargaining, joint city- level initiatives with employers' associations and union mergers and restructuring. It also examines different forms of union organization, including the union as individual servicing agency and as social movement. One strength of this approach is that it underlines the diversity of strategies pursued by US unions and shows that organizing is far from being the most significant or effective strategy of revitalization. A second strength flows from detailed case studies, which are able to bring out some of the constraints on the adoption of particular strategies. For example, a radical shift of resources into union organizing will encounter resistance from existing union officials and members because of a perceived deterioration in the quality of union service. Third, other studies use either the comparative method or time series evidence to analyse variation in union effectiveness. Milkman and Wong's (2001) comparison of successful and failed organizing drives shows that organizing across an entire industry, rather than a single firm, was more successful, other things equal. Shoch (2001) demonstrates that the declining political success of the American Federation of LaborCongress of Industrial Organizations $(\mathrm{AFL}-\mathrm{ClO})$ in blocking free trade measures in the US Congress was a reflection of increased mobilization by the supporters of free trade, including the Democratic President, Bill Clinton. Yet, confining analyses of union strategy to a single country makes it very difficult to shed light on the impact of national institutions and to generalize results to other countries.

A third type of research has investigated a particular strategy across different countries. Although somewhat rare, the 
collection by Fairbrother and Yates (2003) on union organizing in five English-speaking countries is an example. One finding that emerges clearly from the comparison of the United States, the United Kingdom, Canada, Australia, and New Zealand is that union organizing takes different forms in different countries. In Britain and New Zealand, for example, it has been articulated through partnership with employers, whereas in the United States it has developed in a more adversarial form. One issue that arises from this research is that all five countries are examples of a single variety of capitalism, the 'liberal market economy'. The absence of either Coordinated or Mediterranean economies means that, as with single country studies, it is difficult to know whether findings can be generalized to other varieties of capitalism.

The approach adopted in this volume examines a wide range of strategies in diverse union movements across countries that vary along a range of variables. This method has also been used by Waddington and Hoffman (2000a) on the sixteen EU Member States, Martin and Ross (1999) on the United Kingdom, Germany, Sweden, France, Italy, and Spain, Ferner and Hyman's (1998) collected volume, and Harrod and O'Brien (2002) on unions in both the Southern and Northern Hemispheres. The essays in Waddington and Hoffman (2000a) provide detailed descriptions of union initiatives around membership recruitment and union mergers. The editors note substantial variation in the incidence and outcomes of merger activity across Europe. They also point out, however, that one common trend is towards the creation of large multi- occupational, multi-industry unions and away from any type of industrial union structure (Waddington and Hoffman 2000b). Ross and Martin (1999) carefully document the challenges to union membership and power arising out of developments in the economic, political, and industrial relations systems in their six countries. The growth of different forms of flexibility, of decentralized bargaining and of neo-liberal policies on the part of both left and right governments have, in their view, seriously curtailed the scope for a recovery of union membership and power back to the levels of the 'Golden Age' of postwar capitalism. Nonetheless they believe that recovery is possible in those countries where employers and the state still perceive a legitimate and useful role for unions. However, it remains unclear exactly what unions would have to do to consolidate their role as social partners or, in the case of Britain, to acquire such a role. In some countries, then, the continuing importance of unions is thus not taken for granted.

\section{WHY UNION REVITALIZATION?}

Much of the literature discussed above has one-frequently tacit and implicit - assumption: union revitalization is desirable and important. Yet, given the fact that unions in most countries are, to some degree, experiencing a crisis, the question of why one would care about union revitalization at all is a pertinent one. After all, maybe unions have become superfluous in a global economy where national boundaries appear to be of declining importance and where a shift to market regulation within many countries is clearly discernible (Held et al. 1999: 2-14). Thus, a fundamental question is: Does it matter whether and how unions are revitalizing? And, to what extent is union revitalization crucial for the functioning of capitalist economies or democratic polities given the generally accepted dominance of supply-side economic policies? In other words, does the strength of unions make any difference- and if so, for what and for whom? We argue that despite these shifts in the economy and in policies at both the global and national level, unions retain important functions for democracy as well as capitalist economies. 
Conceivably, workers' interests could be represented and expressed (though not necessarily aggregated) through mechanisms that exclude labour unions. The model of the company union, non-union works councils, the provision of individual labour-market services and benefits to members or sophisticated human resource management procedures may each appear as an alternative to the collective representation of workers' interests through unions (see, for example, Kochan 1995: 363; Osterman et al. 2001: 18). If any of these models provide an alternative, then what is the value of unions?

Existing scholarship addresses several aspects of the contributions that unions make to society and the economy. One prominent function of unions is their role in producing macroeconomic outcomes. With respect to economic indicators, such as GDP growth or wage levels, the evidence of the impact of unions is mixed. For the 1970s, it has been argued that countries with encompassing union organizations exhibit better economic performance (Cameron 1984; Calmfors and Driffill 1988). Yet, for the 1990s, these correlations are not evident in cross-national comparisons; no clear links exist, for instance, between union strength and real wage growth or real wage share (Franzese and Hall 2000). However, evidence shows that higher union density is associated with a lower share of low-paid employment and a lower level of income dispersion, lending additional support to research suggesting that strong unions are linked to a compression of the wage structure (Organization for Economic Cooperation and Development (OECD) 2002: 270). Furthermore, union density and the generosity of the welfare state are related to a reduction in the proportion of the workers whose families live in poverty (OECD 2002: 269-70). Bargaining coverage is correlated with higher real wage growth, lower employment and higher unemployment, and higher inflation, but also with lower labour earnings inequality and wage dispersion (Aidt and Tzannatos 2002: 11). Hall and Soskice (2001: 21-2) find that in general, in liberal market economies (LMEs)-where unions are generally weaker-income inequality is higher and working hours are longer for a larger share of the population. To the extent that unions are in many countries involved in affecting welfare state provisions, one can infer an indirect and inverse link between strong, revitalized unions, and working poverty. If one of the functions of unions is considered to be balancing out the inequalities produced by market mechanisms, it appears that they may well make a valuable contribution in this area.

Furthermore, in many countries unions have begun to play a new role in social pacts of varying contents (see Hamann and Kelly, Chapter 6, this volume). This indicates that unions retain an important function in formulating and implementing various wage and welfare-related measures even when membership continues to fall and welfare state retrenchment is common. It appears that unions continue to exercise some measure of policy influence through their participation in these pacts. Powerful unions may also have some impact on the economic strategy a country adopts. For instance, in a country with high density and bargaining coverage, it would be difficult to base economic development on low-wage sectors with poor training (Streeck 1991, 1996). In that sense, strong unions are able to constrain the options for business and thus have some influence on countries' economic paths. However, it could be argued that this is a chicken-and-egg question. After all, strong unions are unlikely to develop in economies that are based on the 'low road' to growth. Given the idea of 'institutional complementarities' (Hall and Soskice 2001: 17), unions are more likely to develop a strong presence where conditions are more favourable. 
A second body of literature links union strength to sector-specific economic outcomes, especially wages (Dunlop 1944; Ross 1948; Wallerstein and Golden 2000; Kaufman 2002). Here the evidence shows that in countries with a substantial nonunion sector, such as the United Kingdom and the United States, unionized workers continue to enjoy a wage premium over their non-union counterparts from a low of 2-3 per cent to a high of 68 per cent (in the construction industry) (Mishel, Bernstein, and Schmitt 2001). In Britain the union wage premium is highest of all for the most disadvantaged groups in the labour market, such as women and ethnic minorities (Metcalf, Hansen, and Charlwood 2000).

Yet, unions are not just economic actors, but also have an important function as democratic actors both in society at large and in the workplace. Workplace democracy and workers' democratic participation rights in the workplace are intrinsically linked to the question of union presence in these workplaces. Workers are more able to influence workplace decisions, to exercise 'voice', where unions are recognized for collective bargaining (Freeman and Medoff 1984). Surveys in the United States and Britain have shown that approximately 50 per cent of employees enjoy less influence over workrelated decisions than they would like and that figure has increased during the past 20 years as union density and bargaining coverage have fallen (Freeman and Rogers 1999: 48-9; Kelly 1998: 46). The question of how unions can enhance the citizenship rights of workers is especially relevant during times of economic hardship (Müller-Jentsch 1994). As market regulation replaces government regulation, the scope of the issues citizens exercise influence on is reduced, and democratic workplace representation might serve as a substitute. Unions can also help to overcome the power imbalance between the individual worker and employers endemic in capitalist systems.

Taking the idea of citizenship beyond the workplace, unions have also been established as integral parts of civil society because they have an .important function in interest aggregation and representation in democratic societies (Hamann 2003). There is evidence, for example, that unions can be effective vehicles in boosting voter turnout (Hamann and Kelly, Chapter 6 , this volume). The question here is not how successful unions are in getting their preferred party or candidate elected, but to what extent they contribute to the quality of democracy by increasing voter turnout in general and by stimulating political awareness and participation among citizens. While some authors bemoan a decline in civil society as Americans have forfeited bowling leagues and instead 'bowl alone' (Putnam 1995), unions in industrialized democracies are still one of the strongest interest associations where citizens 'bowl together' and thus perform an important democratic function. ${ }^{1}$ Similarly unions can contribute to the stock of 'social capital' defined as 'features of social organizations, such as trust, norms and networks that can improve the efficiency of society by facilitating coordinated actions' (Putnam 1993: 167).

In addition, unions also have a political role, frequently serving as valuable allies of political parties in their competition for votes and policies (Stephens and Wallerstein 1991; Smith 1998). They also have a fundamental role in supporting or counterbalancing dominant political and economic ideas and ideologies and therefore broadening the spectrum of political discourse. Furthermore, they have been active participants in formulating policies in cross-class alliances with employers (e.g. Swenson 2002). The implications of unchecked union decline would thus extend to political processes and policy-making dynamics with extensive ramifications for policy outcomes. 
Finally, unions form an integral part of industrial relations systems. Unions are part of the linkages between the actors and the institutions constituting the economic system, or 'institutional complementarities' (see Hall and Soskice 2001: 17). It follows that a fundamental weakening of the position of unions would have profound systemic implications. These would extend not just to unions as organizations or to the representation of workers' collective interests, but to the whole industrial relations and economic systems: production systems, training structures, wage setting and bargaining procedures, policy-making structures, and social welfare regimes would all be affected. If unions all but disappeared, a fundamental reorganization of the economic institutions might be a necessary consequence. This might not be a desirable undertaking in many economies, in particular in coordinated market economies (CMEs), which are based on high skill formation, low worker turnover, and principally cooperative relationships between unions and employers (Thelen 2000). If, however, a fundamental reorientation of economic institutions is deemed necessary in response to global economic pressures, this might be more easily undertaken in conjunction with unions (Thelen 2001: 79). Similarly, other studies have found that bargaining coordination is conducive to the labour market's capacity to absorb shocks quickly and at low employment cost; in addition, where bargaining coverage is high, real wages are more responsive to employment conditions (Aidt and Tzannatos 2002: 111). Maybe it is these kinds of far-reaching implications of a fundamental change in the strength and functions of unions that have led many Western European governments (with the UK liberal market being the exception) to include unions in processes of national concertation during times of economic adjustment (Pochet 1999; Berger and Compston 2002).

In sum, unions continue to be critical actors in capitalist democracies because they form an integral part of a democratic civil society, because they encourage participation in democratic processes, because they represent the interests of those that tend to be underrepresented, because they are able to overcome a crucial collective action problem, and because they add to the interest representation in pluralist societies. Margaret Levi's (2003: 45) claim that 'labor unions are important to American democracy and to the achievement of local, national, and global justice in the twenty-first century' and that organized labor is arguably the most effective popular vehicle for achieving a democratic and equitable society' can most likely be applied to our other country cases as well.

\section{UNION DECLINE AND REVITALIZATION}

\section{IN A GLOBAL WORLD}

If unions retain important functions, what enables them to do so? Comparative research in industrial relations starting with Kerr et al.'s seminal work Industrialism and Industrial Man has pointed to differences in industrial relations systems and the ways in which key elements shape employment relations at the shop floor. While Industrialism and Industrial Man hypothesized the convergence of different national models towards a common system, more recent approaches, focusing on a wider set of key elements within the political economy, assume the perpetuation of three competing patterns of capitalism: CME, LME, and a less clearly defined Mediterranean economy (Hall and Soskice 2001). Besides this general differentiation, unions in the five countries analysed in this book vary not only in terms of their strength, an aspect that is crucial to estimate their chances of revitalization, but also in the institutional framework they are embedded in. Key elements of these institutional frameworks include the degree of coordination and centralization 
of collective bargaining (Calmfors and Drifhl 1988; Soskice 1990; Traxler, Blaschke, and Kittel 2001); the strength, unity, and comprehensiveness of employers' associations (Swenson and Pontusson 2000; Thelen 2000; Traxler 2001); the existence of competent and powerful works councils (Turner 1991; Rogers and Streeck 1994; Frege 2002); the inclusion of labour into corporatist structures at the national or international level (Zagelmeyer 2000; Keller 2001; Baccaro 2002); or involvement in issues of training and skill development (Streeck 1996). In addition national and European employment law regulates strikes, the extension of collective bargaining agreements, and welfare rights, which also affect unions' scope for action (Esping- Andersen 1990; Stokke and Thörnqvist 2001; Traxler and Behrens 2002). Unions in our five countries thus operate under considerably different conditions.

First, the system of collective bargaining displays distinctive variation across the five cases. While the focus of collective bargaining is predominantly at the company level in the LMEs (the United Kingdom and United States), in Germany, collective agreements are mostly negotiated at the industry level. The same is true for Spain, where the sectoral-provincial level dominates with negotiations also occurring at the company and inter-sectoral level. Finally, in Italy a dual system of collective bargaining prevails where industry-wide agreements are complemented by negotiations at the company or territorial level. As emphasized in the varieties of capitalism literature, company-level bargaining strongly correlates with a low degree of bi- or tripartite concertation. As indicated in Table 2.1, unions in Germany, Italy, and Spain were involved in national- level social pacts. Finally, provisions for the extension of collective agreements are important to understand labour's capacity to determine wages, hours, and working conditions. Unions' capacity to set those standards is not exclusively determined by the size of their membership, and so extension provisions can potentially compensate for a low membership level. With differing degrees of effectiveness, such provisions exist in Germany and Spain, and in Italy, which features some functional equivalents to extension. British and American unions have no direct means of influencing the wages and working conditions of non-unionized workers.

As Table 2.1 shows, current levels of collective bargaining coverage vary widely with the two LME countries representing the lower end of the spectrum. If we focus on trends in coverage, Italy and Spain have remained fairly stable, but Germany, the United States and the United Kingdom are witnessing decline. Union density exhibits divergent trends (Table 2.2). While density is declining in Germany and the United States, the United Kingdom, and Italy seem to have halted decline in the late 1990s. In Spain, in contrast, both density and membership grew steadily between 1990 and 2000. In 2000 union density fell into a rather narrow range between 13.5 per cent (the United States) and 31 per cent (Italy). 
Table 2.1. Collective bargaining and social pacts 1990-2000

\begin{tabular}{|c|c|c|c|c|c|}
\hline & $\begin{array}{l}\text { Scope of collective } \\
\text { bargaining }\end{array}$ & $\begin{array}{l}\text { CB } \\
\text { coverage } \\
(2000)\end{array}$ & $\begin{array}{l}\text { CB } \\
\text { coverage, } \\
\text { trend, } \\
\text { 1990-2000 }\end{array}$ & $\begin{array}{l}\text { Extension } \\
\text { provisions }\end{array}$ & $\begin{array}{l}\text { National-level } \\
\text { tri-partite } \\
\text { concertation/ } \\
\text { social pacts }\end{array}$ \\
\hline Germany & $\begin{array}{l}\text { Industry level } \\
\text { dominates, some } \\
\text { company level }\end{array}$ & $67 \%$ & $\begin{array}{c}\text { Continued } \\
\text { decline }\end{array}$ & Yes & $\begin{array}{l}1995-96 ; \\
1998-2002\end{array}$ \\
\hline Italy & $\begin{array}{l}\text { Two level bargaining, } \\
\text { industry and either } \\
\text { company or } \\
\text { territorial level }\end{array}$ & $\begin{array}{l}\text { Approx. } \\
90 \% \text { (for } \\
\text { minimum } \\
\text { wage } \\
\text { levels } \\
\text { only) }\end{array}$ & $\begin{array}{l}\text { Relatively } \\
\text { stable }\end{array}$ & $\begin{array}{l}\text { No, but some } \\
\text { functional } \\
\text { equivalents }\end{array}$ & $\begin{array}{c}1992,1993 \\
1996,1998\end{array}$ \\
\hline Spain & $\begin{array}{l}\text { Sectoral-provincial } \\
\text { level dominates; } \\
\text { also company level } \\
\text { and intersectoral }\end{array}$ & $80 \%$ & $\begin{array}{l}\text { Relatively } \\
\text { stable }\end{array}$ & Yes & $1996 \mathrm{ff}$. \\
\hline UK & Company level & $36 \%$ & $\begin{array}{l}\text { Continued } \\
\text { decline }\end{array}$ & No & No \\
\hline US & Company level & $15 \%$ & $\begin{array}{l}\text { Continued } \\
\text { decline }\end{array}$ & $\begin{array}{l}\text { No, some } \\
\text { functional } \\
\text { equivalents in } \\
\text { some } \\
\text { industries } \\
\text { (construction) }\end{array}$ & No \\
\hline
\end{tabular}

" Data available for the time period 1994-2000 only.

Sources Zagelmeyer (2000); Carley (2002); Hirsch and Macpherson (2003); Traxler and Behrens (2003).

Patterns of inter-union competition also vary substantially across the five cases. In two countries (Spain and Italy) confederations, organized along political orientations, compete with each other, while in Germany, the United Kingdom, and the United States one major confederation heads the national labour movement even though other unions exist outside of these national peak organizations. As indicated in Table 2.3, variation is also notable in the field of industrial conflict with Spain being the most and Germany the least strike-prone country.

As we show in the following section, this variation in key characteristics of the national institutions of industrial relations generate different degrees of urgency to the goal of union revitalization. It also has implications for union perspectives on revitalization and available resources. 
Table 2.2. Union membership trends 1980-2000

\begin{tabular}{lllllll}
\hline & $\begin{array}{l}\text { Union } \\
\text { membership } \\
(1980) \text { in } \\
\text { millions }\end{array}$ & $\begin{array}{l}\text { Union } \\
\text { membership } \\
(1997) \text { in } \\
\text { millions }\end{array}$ & $\begin{array}{l}\text { Union } \\
\text { density } \\
(1980)^{\mathrm{b}}\end{array}$ & $\begin{array}{l}\text { Union } \\
\text { density } \\
(2000)^{\mathrm{b}}\end{array}$ & $\begin{array}{l}\text { Change in } \\
\text { union } \\
\text { density } \\
1980 / 2000\end{array}$ & $\begin{array}{l}\text { Inter-union } \\
\text { competition }\end{array}$ \\
\hline Germany & 9.484 & $\begin{array}{l}10.278 \\
(1998)^{\mathrm{d}}\end{array}$ & 33.6 & 21.6 & -35.7 & No \\
Italy & 9.006 & $10.660^{\mathrm{c}}$ & 44.4 & 31.0 & -30.3 & Yes \\
Spain & $0.643(1981)$ & 1.457 & 5.7 & 13.3 & +133.3 & Yes \\
UK & 12.947 & $7.987(1996)$ & 52.2 & 29.5 & -43.5 & $\begin{array}{l}\text { No } \\
\text { No, some } \\
\text { US }\end{array}$ \\
20.095 & 16.110 & 21.1 & 13.5 & -36.0 & $\begin{array}{l}\text { Norisdictional } \\
\text { disputes }\end{array}$ \\
\hline
\end{tabular}

- Membership figures include pensioners and the unemployed.

' Germany, ltaly. Spain: calculated as active union membership (excluding retired members)/working population (including unemployed); United Kingdom, United States calculated as union members (including retired members)/working population (excluding unemployed).

"Including self-employed.

4 Including east and west Germany.

Sources. Ebbinghaus and Visser (2000); Ebbinghaus (2003); Hirsch and McPherson (2003).

Table 2.3. Working days lost through industrial action per 1,000 employees

\begin{tabular}{lrrrr}
\hline & 1998 & 1999 & 2000 & 2001 \\
\hline Germany & 0.6 & 2.6 & 0.4 & 0.9 \\
Italy & 28.2 & 43.6 & 41.7 & 40.6 \\
Spain & 119.4 & 129.6 & 292.5 & 151.0 \\
UK & 11.0 & 10.0 & 20.0 & 20.0 \\
USA & 42 & 16 & 163 & $\mathrm{~N} / \mathrm{A}$ \\
\hline
\end{tabular}

Source: EIRO (2003).

\section{FOUR DIMENSIONS OF UNION REVITALIZATION}

The previous sections illustrate that union activity is multidimensional and extends to politics, society, and the market (see Hyman 2001 for a similar typology). Similarly, the nature of the crisis unions are facing differs across countries and between unions. Consequently, as union activity is multi-faceted, and unions also derive power resources from the various spheres they engage in, union revitalization can be conceptualized as (re)gaining power along the various dimensions that capture the main orientations or spheres of union activity. ${ }^{2}$ We specify four dimensions along which revitalization can occur; three of these dimensions are derived inductively by observing patterns of union decline and revitalization. We identify the membership dimension, the economic dimension, and the political dimension as those that capture most clearly the different patterns of crisis and renewal. Yet, these dimensions together do not necessarily signal to what extent unions have made active and engaged efforts to revitalize their organizations. We thus add a fourth institutional dimension designed to encompass unions' internal structure, 
dynamics, and identity. We are interested in finding out to what extent the relationship between the institutional dimension and the other three dimensions is interactive. One could argue, for instance, that unions' identity and structures drive, to some extent, the choice of revitalization dimensions and strategies, but are also affected by them and can change in response to shifting emphases on the spheres of union activity (Hyman 1994:119). However, in many cases it is difficult for unions to revitalize along one or more of these three core dimensions unless they also engage in fundamental organizational change.

Figure 2.1 represents the four dimensions of union revitalization as a pyramid. The graphic representation suggests that unions' revitalization efforts can either focus on one dimension, or can be a combination of more than one dimension. Thus, the revitalization efforts of a country's labour movement can be positioned within the space of the pyramid.

\section{Membership Dimension}

Union revitalization along the membership dimension consists of three measurable factors: an increase in membership numbers, an increase in membership density, and a change in the composition of union membership. Rising numbers of union members translate into increased resources for unions, including membership dues and people that can be mobilized in campaigns. Density is a commonly used indicator of union strength because it reflects the share of the workforce that is unionized and thereby has implications for legitimacy, representativeness, and bargaining power. It could be argued, though, that merely increasing membership and/or density by

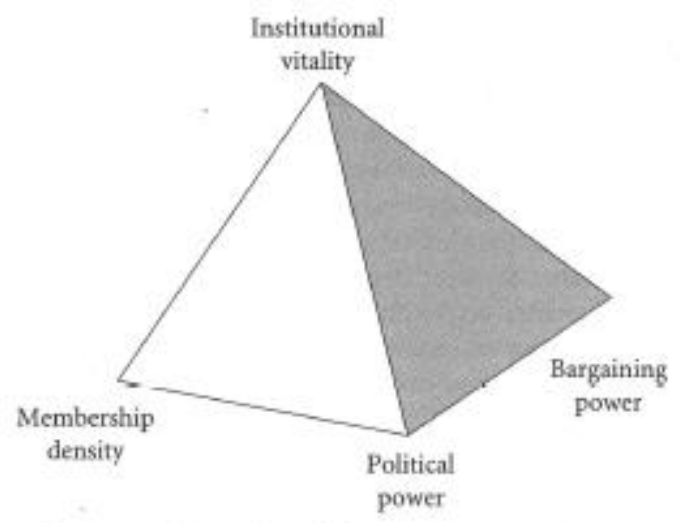

Figure 2.1. Dimensions of labour movenent revitalization

recruiting a larger share of unions' traditional core constituencies does not present sufficient innovation to merit the label 'revitalization. As the composition of the workforce changes, unions may no longer be able to boost their membership by targeting their traditional constituency, for example, male workers with stable employment. In most countries women, immigrants, part-time workers, and workers with temporary contracts constitute a growing share of the workforce. Successful union revitalization thus will include an increase both in membership and in union density, and also appropriate changes in the composition of union membership, thus embracing both a quantitative and qualitative element. 
In addition to outreach to recruit additional members, the membership dimension also contains an internal component. Successful revitalization efforts may depend on changing the attitudes and expectations of existing membership. This may be especially true if external recruitment involves targeting new demographic groups that will change the membership composition and might be resented by the existing membership core. Regardless of which dimension of union revitalization takes priority, an engaged membership increases the potential for progress.

\section{Economic Dimension}

The economic dimension includes bargaining power, the ability to achieve wage and benefit improvements, and more broadly labour's impact on the distribution of wealth. Union revitalization along these lines implies the use of traditional and innovative methods to increase economic leverage. Under the latter heading unions may seek ways to boost their economic influence by developing new techniques outside of bargaining to increase leverage (e.g. corporate campaigns), by modifying deficient bargaining structures, or by redefining the union role in the bargaining process. Often detached from the direct power of union membership, revitalization within the economic realm materializes along different lines. This is because power might be 'derived' from employers' coordination and provisions for the extension of collective agreements. Based on law or on voluntary practice, extension rules broaden unions' direct ability to provide their members with decent wages, hours, and working conditions even where they fail to increase membership density. Ironically, to a substantial degree, unions' capacity for revitalization along the economic dimension depends on their adversaries' organizational strength. In terms of collectively agreed standards, it does not matter so much how many members a union has in a firm so long as the employer is a member of the appropriate employers' association.

\section{Political Dimension}

Revitalization along the political dimension implies that unions improve the effectiveness of their efforts to influence the policy-making process, either through traditional or innovative methods. This dimension involves union interaction with crucial actors at all levels of government-including supra-national bodies such as the European Unionand in three arenas of activity: elections, legislation, and implementation. Unions can seek to improve their leverage in the electoral process by working to secure victory for a political party they are allied with, or by participating more actively

in the selection of candidates and in actual campaigns. In the legislative arena, unions may become more active in drafting or promoting legislation that alters regulation of the industrial relations framework, affects industries and markets where unions represent or are trying to recruit workers, or improves social conditions for union and non-union members alike. Unions may also seek to increase influence with government administration, particularly through enforcement of legislation relevant to union organizing or bargaining or the protection of workers' rights (the regulations in question may relate to the industrial relations framework or to a relevant product or labour market).

\section{Institutional Dimension}

The institutional dimension addresses unions' organizational structures and governance, as well as internal dynamics. It comprises unions' capacity to adjust to new contexts, internal enthusiasm to embrace new strategies, and a 
sense of introducing something new and 'fresh' to the union that is not adequately captured by the other three dimensions. A key aspect is the role of union leaders who promote new ideas and build internal political will to support change. Revitalization along the institutional dimension is sometimes spearheaded by changes in the other three dimensions. For instance, a new emphasis on organizing groups that were previously marginalized within union structures can lead to the creation of new departments (e.g. for women or immigrants), which can then influence the unions' larger goals and eventually lead to a redefinition of strategies. New bargaining approaches, such as corporate campaigns, may have similar effects-increasing the importance of research and public relations functions, for instance. Innovative leadership in unions can also reorient the union's identity, which subsequently has an impact on the choice of revitalization dimensions.

Revitalization along institutional lines does not clearly emerge out of observed indicators of union strength or decline as it is a concept that is difficult to measure. It is striking that unions overall seem to be rather reluctant to engage in profound organizational change that goes beyond adjusting particular strategies. In fact, an interesting question is why union organizations appear so reluctant to adapt and to innovate in the face of new external (and sometimes internal) pressures. Thinking more generally about how unions can be conceptualized theoretically improves our understanding of why the institutional dimension is crucial for union revitalization and at the same time so difficult to target. In particular, comprehending unions as organizations further illuminates the mechanisms that work within unions in their quest to identify new strategies for revitalization and offers some insights into the dynamics that may prevent unions from rapid internal adjustment to new circumstances.

Organizational theory identifies unions as formal interest organizations. While definitions of organizations vary widely, the core of any organization can be defined by two aspects. 'First, the formal organization was seen as being directed towards explicit and clear goals. And second, the organization was seen as an instrument that was to be designed to achieve those goals with the greatest efficiency or economy of resources' (Nohria and Gulati 1994: 531). Weber (1980: 124) defines the 'ideal type' of the most efficient and stable organization as the modern bureaucracy with the following characteristics: a hierarchy, a management system based on written rules, a discrete set of jurisdictional areas and 'roles', an impersonal rule-governed environment and technical criteria for recruitment and promotion. The emphasis on rules, stability, and engrained culture may slow down initiatives for change and may also legitimate resistance to change on the grounds that it violates traditional cultural norms and threatens organizational stability (Voss and Sherman 2000).

Organizational analysis points to resource dependence and contingency theories to show that unions will use strategies that 'fit' their environment (Katz, Batt, and Keefe 2003). These approaches have demonstrated much potential when it comes to understanding why and how unions change to become revitalized. Other strands of organizational theory provide us with good reasons for why rapid change occurs only rarely. Scholars working in the tradition of'population ecology' or 'ecological theory' (Hannan and Freeman 1989) as well as evolution theorists (Nelson and Winter 1982) argue that organizational change is limited by strong inertial pressures. From this perspective, rules, norms, and culture play an important role in the process of organizational change and thus 
determine, even more so than market competition, the selection of efficient organizational structures and processes.

The focus of these approaches on the intersection between organizations and their environment is potentially of high value to understanding labour's specific space for maneuver. Organizational theory contributes to deepening our understanding of how unions may employ resources internal to the union organization -in particular to reduce their dependence on external resources-and how they adapt their internal organizational structure to fit their external environment. ${ }^{4}$ This illustrates the problems union movements have evidenced in reforming their identities and structures that are sometimes a precondition and at other times a consequence of the changes that accompany revitalization efforts.

\section{CONCLUSION: REVITALIZATION AS A CONTEXT-DEPENDENT PROCESS}

Revitalization can be conceptualized in terms of either an ongoing, and incomplete, process, or as an outcome, along four dimensions. We posit that in our country cases, it is the former use of the term that is more meaningful. We can observe revitalization efforts of various types in all five countries, maybe more timid in some than in others, but we shy away from calling any of the national union movements successfully 'revitalized'. In their endeavour to revitalize, unions may well reshape their identities and goals, and may fundamentally redefine their role in society, politics, and the marketplace (Hyman 2001). Such changes indicate the need for flexibility in our indicators of union strength and success.

While all four dimensions of union revitalization are of significance for all five countries, the relative import of each of these dimensions varies across the cases. This is hardly surprising given that the position of unions is context-dependent, that is, hinges on the specific political, economic, and legal provisions that regulate union activity and places unions in the larger political and economic system. The differential focus of national union movements on these dimensions is also shaped by the nature of the crisis that unions find themselves in. For instance, if membership has fallen drastically but has not substantially affected unions' power in the marketplace (e.g. bargaining coverage rates have remained constant), we would probably not expect the same priority on membership as a revitalization strategy as in a case where dwindling membership rates have resulted in similarly reduced bargaining coverage rates. Where unions' rights on the shop floor are supplemented by the parallel existence of works councils, they might similarly find that the membership dimension is of less immediacy for revitalization than in cases where they are the only intermediary between workers and management.

The specific national context does matter, but we do not mean to imply that the dimensions of revitalization unions target are entirely determined by their position in their national industrial relations, political, or economic systems. Instead, we view these exogenous variables as influential and constraining, but not determinant. Unions, as organizations, have some leeway in deciding whether they want to focus their efforts and resources on gaining political or market power or both, whether pursuing internal organizational or leadership changes is vital to their renewal efforts, and how crucial the membership dimension is. Union leaders can, within the constraints of their national contexts and union organizations, decide on the most promising revitalization dimensions and pick strategies they identify as conducive to furthering revitalization along those dimensions. We thus introduce the element of Strategie choice (see Child, Loveridge, and Warner 1973; Kochan, Katz, and McKersie 1986; Swenson 1989; Johnston 1994) to our explanation of the variation in 
importance of revitalization dimensions in our cases.

The following chapter outlines further the strategies unions in the different countries have engaged in to regain strength. Subsequent chapters analyse the efforts of major unions in five countries by comparing how, why, and to what effect they have employed these strategies of union revitalization.

\section{Notes}

1. In Britain, for example, approximately 200,000 workers acted as unpaid union representatives at their workplace in 1998 (Millward et al. 2000: 155).

2. Although we label these different aspects of union activity 'dimensions', no one term can fully capture our intent. On the one hand the four aspects are indicators of revitalization, on the other hand they are power resources that drive revitalization. Our adoption of the term 'dimensions' should not be interpreted as limiting the importance of these four factors.

3. As Powell and DiMaggio (1991) have shown, the same plurality of concepts and definition is also true for institutions in the case of defining institutions.

4. Nonetheless, despite their merits, organizational theories also have limits in their application and explanatory power. For instance, they cannot account for cases of vibrant labour protest, short and punctuated periods of time where labour movements are born. While resource dependence and contingency theories help to understand how labour (as an organization) handles a complex and uncertain environment by way of diversification, they do not tell us why-at certain times and at certain places-labour is capable of challenging powerholders by mobilizing thousands of people on the streets.

\section{References}

Aidt, T. and Tzannatos, Z. (2002). Unions and Collective Bargaining: Economic Effects in a Global Environment. Washington, DC: The World Bank.

Baccaro, L. (2002). 'Negotiating the Italian Pension Reform with the Unions: Lessons for Corporatist Theory'. Industrial and Labor Relations Review, 66/3: 579-601.

Berger, S. and Compston, H. (2002). Policy Concertation and Social Partnership in Western Europe: Lessons for the 21st Century. New York: Berghahn.

Bronfenbrenner, K. and Juravich, T. (1998). 'It takes more than House Calls: Organizing to Win with a Comprehensive Union-Building Strategy', in K. Bronfenbrenner, S. Friedman, R. W. Hurd, R. A. Oswald, and R. L. Seeber (eds.), Organizing to Win: New Research on Union Strategies. Ithaca, NY: ILR Press, 19-36.

Friedman, S., Hurd, R. W., Oswald, R. A., and Seeber, R. L. (eds.) (1998). Organizing to

Win: New Research on Union Strategies. Ithaca, NY: ILR Press. 
Calmfors, L. and Driffill, J. (1988). 'Bargaining Structure, Corporatism, and Macroeconomic Performance'. Economic Policy, 6: 13-61.

Cameron, D. (1984). 'Social Democracy, Corporatism, Labour Quiescence, and the Representation of Economic Interest in Advanced Capitalist Societies', in J. Goldthorpe (ed.), Order and Conflict in Contemporary Capitalism. Oxford: Clarendon Press, 143-78.

Carley, M. (2002). 'Industrial relations in the EU, Japan and USA, 2001'. EIRO, www.eiro. eurofound.ie/2002/12/feature/TN0212101F.html.

Child, J., Loveridge, R., and Warner M. (1973). 'Towards an Organizational Study of Trade Unions'. Sociology, 7/1: 7199.

Clawson, D. (2003). The Next Upsurge: Labor and the New Social Movements. Ithaca, NY: ILR Press.

Dunlop, J. T. (1944). Wage Determination Under Trade Unions. New York: Macmillan.

Ebbinghaus, B. (2003). 'Die Mitgliederentwicklung deutscher Gewerkschaften im historischen und internationalen Vergleich', in W. Schröder and B. Weßels (eds.), Die Gewerkschaften in Politik und Gesellschaft der Bundesrepublik Deutschland. Ein Handbuch. Wiesbaden: Westdeutscher Verlag, 74-203.

and Visser, J. (2000). Trade Unions in Western Europe since 1945. London: Macmillan.

EIRO (2003). Developments in Industrial Action 1998-2002, www.eiro.eurofound.ie/ 2003/03/Update/TN0303104U.html. Esping-Andersen, G. (1990). The Three Worlds of Welfare Capitalism. Princeton, NJ: Princeton University Press.

Franzese, R. J. and Hall, P. A. (2000). 'Institutional Dimensions of Coordinating Wage Bargaining and Monetary Policy', in T. Iversen, J. Pontusson, and D. Soskice (eds.), Unions, Employers, and Central Banks: Macroeconomic Coordination and Institutional Change in Social Market Economies. New York: Cambridge University Press, 173-204.

Fairbrother, P. and Yates, C. A. B. (eds.) (2003). Trade Unions in Renewal: A Comparative Study. London: Continuum. Ferner, A. and Hyman, R. (eds.) (1998). Changing Industrial Relations in Europe, 2nd edn. Oxford: Blackwell.

Freeman, R. B. and Medoff, J. L (1984). What do Unions Do? New York: Basic Books.

and Rogers, J. (1999). What Workers Want. Ithaca, NY: ILR Press.

Frege, C. (2002). 'A Critical Assessment of Theoretical and Empirical Research on German Works Councils'. British Journal of Industrial Relations, 40/2: 221-48.

Gall, G. (ed.) (2003). Union Organizing: Campaigning for Trade Union Recognition. London: Routledge.

Gordon, M. E. and Turner, L. (eds.) (2000). Transnational Cooperation Among Labor Unions. Ithaca, NY: ILR Press.

Hall, P. A. and Soskice, D. (2001). 'An Introduction to the Varieties of Capitalism', in P. A. Hall and D. Soskice (eds.), Varieties of Capitalism: The Institutional Foundations of Comparative Advantage. Oxford: Oxford University Press, 1-70. 
Hamann, K. (2003). 'European Integration and Civil Society in Spain'. South European Society and Politics. 8/1: 47-68.

Hannan, M. T. and Freeman, J. (1989). Organizational Ecology. Cambridge: Harvard University Press.

Harrod, J. and O'Brien, R. (eds.) (2002). Global Unions? Theory and Strategies of Organized Labour in the Global Political Economy. London: Routledge.

Held, D., McGrew, A., Goldblatt, D., and Perraton, J. (1999). Global Transformations: Politics, Economics and Culture. Cambridge: Polity Press.

Hirsch, B. and McPherson, D. (2003). Union Membership and Coverage Database from the Current Population Survey, www.unionstats.com.

Hyman, R. (1994).j'Changing Trade Union Identities and Strategies', in R. Hyman and A. Ferner (eds/J, New Frontiers in European Industrial Relations. Oxford: Basil Blackwell, 108-39. (2001). Understanding European Trade Unionism: Between Market Class and Society. London: Sage.

Johnston, P. (1994). Success while others Fail. Social Movement Unionism and the Public Workplace. Ithaca, NY: ILR Press.

Katz, H. C., Batt, R., and Keefe, J. H. (2003). 'The Revitalization of the CWA: Integrating Collective Bargaining, Political Action, and Organizing' Industrial and Labor Relations Review, 56/4: 573-89.

Kaufman, B. E. (2002). 'Models of Union Wage Determination: What have we Learned since Dunlop and Ross?'. Industrial Relations, 41/1: 110-58.

Keller, B. (2001). 'Social Partners and Social Partnership at the European Level', in C. Kjaergaard, and S.-Ä. Westphalen (eds.) From Collective Bargaining to Social Partnerships: New Roles of the Social Partners in Europe. Copenhagen: The Copenhagen Centre.

Kelly, J. (1998). Rethinking Industrial Relations: Mobilization, Collectivism and Long Waves. London: Routledge.

and Willman, P. (eds.) (2004). Union Organization and Activity. London: Routledge.

Kochan, T. A. (1995). 'Using the Dunlop Report to Achieve Mutual Gains'. Industrial Relations, 34/3: 350-66.

Katz, H., and McKersie, R. (1986). The Transformation of American Industrial Relations.

New York: Basic Books.

Levi, M. (2003). 'Organizing Power: The Prospects for an American Labor Movement'. Perspectives on Politics, 1/1: 45-68. Martin, A. and Ross, G. (eds.) (1999). The Brave New World of European Labor: European Trade Unions at the Millennium. New York: Berghahn Books.

Metcalf, D., Hansen, K., and Charlwood, A. (2000). Unions and the Sword of Justice: Unions and Pay Systems, Pay Inequality, Pay Discrimination and Low Pay. London: London School of Economics, Centre for Economic Performance, Discussion Paper 452. 
Milkman, R. and Wong, K. (2001). 'Organizing Immigrant Workers: Case Studies from Southern California', in L. Turner, H. C. Katz, and R. W. Hurd (eds.), Rekindling the Movement: Labor's Quest for Relevance in the 21st Century. Ithaca, NY: ILR Press, 99-128. Millward, N., Bryson, A., and Forth, J. (2000). All Change at Work? British Employment Relations 1980-1998, as Portrayed by the Workplace Industrial Relations Survey Series. London: Routledge.

Mishel, L., Bernstein, J., and Schmitt, J. (eds.) (2001). The State of Working America 2000-01. Ithaca, NY: Cornell University Press.

Müller-Jentsch, W. (1994). 'Über Produktivkräfte und Bürgerrechte', in N. Beckenbach and W. van Treeck (eds.), Umbrüche gesellschaftlicher Arbeit. Göttingen: Sonderband 9 Soziale Welt, 643-61.

Nelson, R. and Winter, S. (1982). An Evolutionary Theory of Economic Change. Cambridge: Harvard University Press.

Nissen, B. (ed.) (2002). Unions in a Globalized Environment: Changing Borders, Organizational Boundaries, and Social Roles. New York: ME Sharpe.

Nohria, N. and Gulati, R. (1994). 'Firms and Their Environments', in N. Smelser and R. Swedberg (eds.), The Handbook of Economic Sociology. Princeton, NJ: Princeton University Press, 529-55.

OECD (2002). Employment Outlook. Paris: OECD.

Osterman, R, Kochan, T. A., Locke, R. M., and Piore, M. J. (2001). Working in America.

A Blueprint for the New Labor Market. Cambridge and London: MIT Press.

Pochet, P. (ed.) (1999). Monetary Union and Collective Bargaining in Europe. Brussels: Peter Lang.

Powell, W. W. and DiMaggio, P. J. (1991). 'Introduction, in W. W. Powell and P. J. DiMaggio (eds.), The New Institutionalism in Organizational Analysis. Chicago and London: University of Chicago Press, 1-38.

Putnam R. (1993). Making Democracy Work: Civic Traditions in Modern Italy. Princeton, NJ: Princeton University Press. (1995). 'Bowling Alone: America's Declining Social Capital'. Journal of Democracy, 6/1: 65-78.

Rogers, J. and Streeck, W. (eds.) (1994). Works Councils. Chicago IL: University of Chicago Press.

Ross, A. (1948). Trade Union Wage Policy. Berkeley CA: University of California Press.

Ross, G. and Martin, A. (1999). 'Through a Glass Darkly', in A. Martin and G. Ross (eds.), The Brave New World of European Labor: European Trade Unions at the Millennium. New York: Berghahn Books, 368-99.

Shoch, J. (2001). 'Organized Labor Versus Globalization: NAFTA, Fast Track and PNT with China', in L. Turner, H. C. Katz, and R. W. Hurd (eds.), Rekindling the Movement: Labor's Quest for Relevance in the 21st Century. Ithaca, NY: ILR Press, 275-313.

Smith, W. R. (1998). The Left's Dirty Job: The Politics of Industrial Restructuring in France and Spain. Pittsburgh PA: University of Pittsburgh Press. 
Soskice, D. (1990). 'Wage Determination: The Changing Role of Institutions in Advanced Industrialized Countries'. Oxford Review of Economic Policy, 6: 36-61.

Stephens, J. D. and Wallerstein, M. (1991). 'Industrial Concentration, Country Size, and Trade Union Membership'. American Political Science Review, 85/3: 941-54.

Stokke, T. A. and Thörnqvist, C. (2001). Industrial Conflict in the Nordic Countries: Convergence or Divergence? Paper presented at the 6th European IIRA Congress, Oslo, June 2001.

Streeck, W. (1991). 'On the Institutional Conditions of Diversified Quality Production', in E. Matzner, and W. Streeck, (eds.), Beyond Keynesianism: The Socio-Economics of Production and Employment. London: Edward Elgar, 21-61.

- - (1996). 'Lean Production in the German Automobile Industry: A Test Case for Convergence Theory', in S. Berger and R. Dore (eds.), National Diversity and Global Capitalism. Ithaca, NY: Cornell University Press, 138-70.

Swenson, P. (1989). Fair Shares. Unions, Pay, and Politics in Sweden and West Germany. Ithaca, NY: Cornell University Press.

(2002). Capitalists Against Markets. New York: Oxford University Press.

and Pontusson, J. (2000). 'The Swedish Employer Offensive against Centralized

Bargaining', in T. Iversen, J. Pontusson, and D. Soskice, (eds.), Unions, Employers, and Central Banks. Macroeconomic Coordination and Institutional Change in Social Market Economies. New York: Cambridge University Press, 77-106.

Taylor, P. and Bain, P. (2003). 'Call Centre Organizing in Adversity: From Excell to Vertex', in G. Gall (ed.), Union Organizing: Campaigning for Trade Union Recognition. London: Routledge, 153-72.

Thelen, K. (2000). 'Why German Employers Cannot Bring Themselves to Dismantle the German Model', in I. Torben, J. Pontusson, and D. Soskice (eds.), Unions, Employers and Central Banks: Macroeconomic Coordination and Institutional Change in Social Market Economies. New York: Cambridge University Press, 138-172.

(2001). 'Varieties of Labor Politics in the Developed Democracies', in P. A. Hall and

D. Soskice (eds.), Varieties of Capitalism: The Institutional Foundations of Comparative Advantage. Oxford: Oxford University Press, 71-103.

Traxler, E (2001.) 'Der verbandliche Organisationsgrad der Arbeitgeber: ein internationaler Vergleich', in J. Abel, and H. J. Sperling (eds.), Umbrüche und Kontinuitäten. Perspektiven nationaler und internationaler Arbeitsbeziehungen. Munich and Mering: Rainer Hampp Verlag, 315-30.

and Behrens, M. (2003). 'Collective bargaining coverage and extension procedures'.

EIRObserver, 2/2003: i-viii.

Blaschke, S., and Kittel, B. (2001). National Labour Relations in Internationalized

Markets. A Comparative Study of Institutions, Change, and Performance. Oxford: Oxford University Press. 
Turner, L. (1991). Democracy at Work. Changing World Markets and the Future of Labor Unions. Ithaca, NY: Cornell University Press.

Katz, H. C, and Hurd, R. W. (eds.) (2001). Rekindling the Movement: Labor's Quest for

Relevance in the 21st Century. Ithaca, NY: ILR Press.

Voss, K. and Sherman, R. (2000). 'Breaking the Iron Law of Oligarchy: Union Revitalization in the American Labor Movement'. American Journal of Sociology, 106/2: 303-49.

(2003).. 'You Just can't do it Automatically: The Transition to Social Movement

Unionism in the United States', in P. Fairbrother and C. A. B. Yates (eds.), Trade Unions in Renewal: A Comparative Study. London: Continuum, 51-77.

Waddington, J. and Hoffman, R. (eds.) (2000a). Trade Unions in Europe: Facing Challenges and Searching for Solutions. Brussels: European Trade Union Institute.

(2000b). 'Trade Unions in Europe: Reform, Organisation and Restructuring', in

J. Waddington and R. Hoffman (eds.), Trade Unions in Europe: Facing Challenges and Searching for Solutions. Brussels: European Trade Union Institute, 27-79.

Wallerstein, M. and Golden, M. (2000). 'Postwar Wage Setting in the Nordic Countries', in T. Iversen, J. Pontusson, and D. Soskice (eds.), Unions, Employers, and Central Banks: Macroeconomic Coordination and Institutional Change in Social Market Economies. New York: Cambridge University Press, 107-37.

Weber, M. (1980, first published 1922) Wirtschaft und Gesellschaft. Grundriss der verstehenden Soziologie, 5th rev. edn. Tübingen: J. C. B. Mohr.

Wever, K. (1997). 'International Labor Revitalization: Enlarging the Playing Field', Industrial Relations, 37/3: 388-407.

Wheeler, H. N. (2002). The Future of the American Labor Movement. New York: Cambridge University Press.

Zagelmeyer, S. (2000). Innovative Agreements on Employment and Competitiveness in the European Union and Norway.

Dublin: European Foundation for the Improvement of Living and Working Conditions. 